\title{
EDITH WHARTON'S “SKETCH OF AN ESSAY ON WALT WHITMAN"
}

\author{
SUSAN GoOdMaN
}

Imagine Henry James and Edith Wharton spending a long, delicious October day motoring through the hills of Lenox, Massachusetts. They've picnicked on hot coffee, oranges, salads, chicken, and chocolate; they've wrapped themselves in the crazy quilt of fall colors and feasted on each other's company. They're now in the library, before the evening fire, Wharton petting the Pekinese curled in her lap and smoking one of her perpetual cigarettes. James idly takes up a stray book and begins to read. "When lilacs last in the door-yard bloom'd," he begins, and Wharton thinks: "I had never before heard poetry . . . He chanted it, and he was not afraid to chant it, as many good readers are." ${ }^{1}$ Far from shirking the rhythmic emphasis James gave it full expression: "His stammer ceased as by magic as soon as he began to read," Wharton writes in her memoir, A Backward Glance (1934),

and his ear, so sensitive to the convolutions of an intricate prose style, never allowed him to falter over the most complex prosody, but swept him forward on great rollers of sound until the full weight of his voice fell on the last cadence. $(A B G, 185)$

James read from his soul, she tells us, and "no one who never heard him read . . . knows what that soul was" $(A B G, 186)$. That October evening James crooned in a mood of subdued ecstasy "till the fivefold invocation to Death" in "Out of the Cradle Endlessly Rocking" "tolled out like the knocks in the opening bars of the Fifth Symphony" ( $A B G, 186)$. members,

"We talked long that night of 'Leaves of Grass,'" Wharton re-

tossing back and forth to each other treasure after treasure; but finally James, in one of his sudden humorous drops from the heights, flung up his hands and cried out with the old stammer and twinkle: 'Oh, yes, a great genius; undoubtedly, a very great genius! Only one cannot help deploring his too-extensive acquaintance with the foreign languages.' $(A B G, 186)$

"I don't believe in God," Wharton would say, "but I do believe in His saints."2 Her "Sketch of an Essay on Walt Whitman" shows that she thought Whitman one of those saints. The essay was to include four major sections. The first would state what other critics had said of Whitman; the second give his philosophy of life, the third his choice of 
subjects, and the fourth analyze his use of "vowel-colour," melody, rhythm, and repetition. Wharton selected the lines quoted in this essay from the 1891-92 edition of Leaves of Grass and organized them under the headings of "Phrases": "Imaginative," "Cosmic," and "Descriptive."

Like many of her contemporaries, Wharton was most drawn to the "Cosmic Whitman." 3 Although she had accepted "the dogmatic, rationalist materialism of the late nineteenth century and professed herself quite satisfied with the notion of human life as a "flash of consciousness between the darkness and the dear" ("E.W.," 33), reflection had taught her how inadequately this view explained human experience. In Whitman, she sought what she later located in the Catholic Church, a frame for the three major life occurrences: birth, marriage, and death. ${ }^{4}$ For the first twelve years of her unfulfilling marriage, Wharton had lived "in a kind of torpor" $(A B G, 122)$; by 1899 , she "wanted above all to get to know other writers, to be welcomed among people who lived for the things" she "had always secretly lived for" ( $A B G, 123)$. Her spirit responded to the lines: "Equable, natural, mystical Union thou, (the mortal with immortal blent,) / Shalt soar toward the fulfilment of the future, the spirit of the body and the mind, / The soul, its destinies."

Wharton outlined the essay in 1908, the same year she began her most scathing analysis of the materialism of American culture in The Custom of the Country (1913). Its heroine, Undine Spragg, is, in some ways, a nightmarish version of Whitman's multitudinous, all-embracing self. Nothing more than a bundle of needs, Undine seeks to find herself "immeasurably magnified in every pair of eyes" she meets. ${ }^{6}$ The quest takes her from the Midwest to old New York to the Fauborg, where she betrays everyone who's fool enough to believe that because she copies their ways and picks up their slang, she understands "anything about the things that make life decent and honourable" for them $(C C, 307)$. Undine appropriates and then consumes the lives and cultures she encounters.

To Wharton, Whitman offered the comfort of an alternative vision, one based on communion and community. In categorizing his use of the adjective, for example, she focused on its inclusiveness and immaterialism, its ability to extend and generate meaning:

There is the adjective of direct observation carried to the highest point of accuracy \& coupled with the most suggestive image: Leopard-coloured rills \& there is the allusive adjective which, while not describing the concrete object as it presents itself to the eye, suggests it as it presents itself to the imagination: alien cone. ${ }^{7}$

Wharton particularly valued the "allusive adjective." "The best adjective," she writes, "is that which while most vividly embodying the 
salient quality of the thing described or its external appearance throws light upon the greatest number of these indirect associations with which the simplest object has become gradually encrusted by the slow accretions of thought" ("Sketch"), as in "uttering joyous leaves of dark green" (Leaves, 105). In "The Criticism of Fiction" (1914), she translated this preference for the allusive adjective into a literary standard: the foundation of a novelist's art is the "life-evoking faculty"; the value of a book is the light it casts "on questions beyond its borders." 8

Whitman appealed to the side of Wharton's own nature she called "the accepting soul" as opposed to "the dissecting intellect" ( $A B G$, 159). "He sees through the layers of the conventional point of view \& of the conventional adjective, straight to the thing itself, not only to the thing in itself, but to the endless thread connecting it with the universe" ("Sketch"). As an example, she cites,

the poor grass plot $\&$ place

What it will do when it is man.

Wharton thought that "this sense of the absolute behind the relative" gave to Whitman's adjectives "their startling, penetrating quality, their ultimateness." "His epithets, his images, go straight to the intrinsic quality of the thing described to "the inherences of things" ("Sketch"). Like Whitman, Wharton valued the "universal"-although she tended to locate it in eighteenth-century Italy. Responding less to the content and more to the rhythm, sound, and the attendant sensuality of Leaves of Grass, she was able to ignore its "promiscuous" or ubiquitous masses, that haphazard jumble of American society, which she had little contact with in life. Wharton believed that Whitman's greatness lay in his originality, and she marked the lines: "Come said the Muse, / Sing me a song no poet yet has chanted, / Sing me the universal" (Leaves, 181).

Conscious of the inadequacy of language, Wharton also respected its latent power to define or destroy this most tenuous-and ultimately most fictive-of worlds. She chose the following lines as an example of Whitman's philosophy:

Come now I will not be tantalized, you conceive too much of articulation,

Do you not know $\mathrm{O}$ speech how the buds beneath you are folded?

Waiting in gloom, protected by frost,

The dirt receding before my prophetical screams,

I underlying causes to balance them at last,

My knowledge my live parts, it keeping tally with the meaning of all things,

Happiness (which whoever hears me let him or her set out in search of this day.)

(Leaves, 50)

In a sense, this passage offered Wharton a new plot. Loss need not lie at the core of consciousness, itself dependent upon the acquisition of an 
amorphously evolving vocabulary. If there is another language contained within the self, then women can escape the inhibiting storylines found in novels of manners and marriage; they can live their lives, like Undine Spragg in The Custom of the Country, guided by nothing save appetite, or, like Ellen Olenska in The Age of Innocence (1920), beyond the stranglehold of convent: $n$.

Although it may be difficult to envision any similarities between the poet of the people and the chronicler of upperclass old New York, Wharton's reading of Whitman reinforced her faith in the soundness of "good English" (slang could be used for a purpose) and her belief in the supremacy of art and the artist, "whose thoughts are the hymns of the praise of things" (Leaves, 269). He too heard the grasses speak and words sing, "O something ecstatic and undemonstrable! O music wild" (Leaves, 29). Particularly valuing his ability to observe "Nature as a seer, not a Naturalist" ("Sketch"), she found another soul who lived in reality and "in dreams' projections" (Leaves, 243). Whitman gave her permission to be an artist, to sing her individual song. Above all, he provided a model of a self-made man, something Wharton ironically liked to think herself. Her autobiography, which borrows its title from his, A Backward Glance O'er Travel'd Roads, shows her trying to articulate the forces-physical, emotional, moral, intellectual, and aesthetic - that shaped her personality. Her memoir's truncated title, $A$ Backward Glance, which almost begs the reader to place Wharton's vision alongside Whitman's as an American original, perhaps comments on the different, though related, roads she saw them travelling: his, imaginatively solid beneath his feet; hers, in recollection.

One year before Wharton began her sketch for the essay, she cut ties with the United States and settled in France. The move represented her attempt to stand "at ease in Nature," to be "the mistress of all" (Leaves, 16). In truth, Wharton had been for a year the mistress of William Morton Fullerton, a bi-sexual journalist with a history of liaisons with older, literarily-inclined women. Fullerton made her feel what she thought happy women feel: passion and abjection. "[A] certain consistency of affection," she admonished her vascillating lover, "is a fundamental part of friendship. One must know à quoi s'en tenir" (where one stands). ${ }^{9}$ How, then, could Wharton, alternately ecstatic and lovesore, read Leaves of Grass and observe that Whitman's treatment of love and the lover was asexual? I'd like to suggest that she didn't. The critic and the "lady" might have had no other way to discuss the sexuality that permeates the poem except in terms of platonic love, but the woman seems to have coded her copy, made a text within a text that spoke to the spiritual and sexual selves she was in the process of exploring. To illustrate descriptive phrases, for instance, Wharton selected "The Dalliance of the Eagles," with its image of "rushing amorous contact high 
in space" (Leaves, 216). Marked lines consciously or unconsciously frame passages like "My lovers suffocate me, / Crowding my lips, thick in the pores of my skin" (Leaves, 72). In a sense, they become the yoke and the sill to windows, such as the lines:

And a compend of compends is the meat of a man or woman,

And a summit and flower there is the feeling they have for each other,

And they are to branch boundlessly out of that lesson until it becomes omnific,

And until one and all shall delight us, and we them. (Leaves, 53)

To echo Whitman, perhaps she dared not tell it in words, not even in these songs.

The year after Wharton completed her sketch, 1909, she wrote her best and most Whitmanesque poem, "Terminus," which she presented to Fullerton, with the request that he return it. He did-but not before making a copy. The title refers to the station hotel where she spent a night with Fullerton and to the temporary end of their relationship as she returned to her husband.

Wonderful was the long secret night you gave me, my Lover,

Palm to palm, breast to breast in the gloom. . . .

Smiles (if such there ever were) like your smile and mine when they met

Here, in this self-same glass, while you helped me to loosen my dress,

And the shadow-mouths melted to one, like the sea-birds that meet in a wave-

Such smiles, yes, such smiles the mirror perhaps has reflected;

And the low wide bed, as rutted and worn as a high road,

The bed with its soot-sodden chintz, the grime of the brasses,

That has born the weight of fagged bodies, dust-stained, averted in sleep,

The hurried, the restless, the aimless-perchance it has also thrilled

With the pressure of bodies ecstatic, bodies like ours,

Seeking each other's souls in the depths of unfathomed caresses,

And through the long windings of passion emerging again to the stars. . . ${ }^{10}$

In both images and rhythm, the poem recalls Leaves of Grass, and it presents a very different portrait of an author often characterized as a cold, imperious society matron or the heiress of Henry James.

Wharton's affair with Fullerton ended around 1910. The oblivion she subsequently found was in her work, although it tended, as the poem suggests and her novella about Whitman demonstrates, to separate, rather than connect, her to others. In The Spark, a young man tries to uncover what has made Hayley Delane different from the other men of his class in the 1890s. Delane cares little about seeing his name on a project as long as the project is completed, and he'll beat a man for mistreating a horse, not for dallying with his wife. When the narrator hears that Delane served in the Civil War, he's convinced that somehow that experience changed him. But the war affected Delane less than the 
big backwoodsman who was awfully good to him in the hospital after Bull Run. Delane attributes his Christian charity to the old heathen who used to come and talk with him by the hour in Washington. "One day he didn't turn up," he tells his young friend. "And soon afterward I was off again, and didn't think of him for years. Then, one day, I had to settle something with myself ind, by George, there he was, telling me the right and wrong of it! Queer-ne comes like that, at long intervals; turning-points, I suppose."11

In the narrator's library, Delane meets him again, his face staring from the frontispiece of a book. "How on earth did the old boy get his portrait in a book?" he asks, and the narrator begins to read from Drum-Taps (which Wharton misquoted):

Young man, I think I know you-I think this face of yours is the face of the Christ himself;

Dead and divine, and brother of all, and here again he lies.

Finishing, he steals a glance at Delane, whose face "was a blank, still composed in the heavy folds of enforced attention. No spark had been struck from him" (Spark, 105).

"Did he write that?" Delane asks.

"Yes; just about the time you were seeing him, probably."

"What do you . . . er . . . call it . . exactly?"

Delane ventured. . . .

"Why poetry ... rather a free form, of course . . .

You see, he was an originator of new verse-forms . .."

When the narrator reveals the poet's name, Delane muses: "Yes; that's it. Old Walt - that was what all the fellows used to call him. He was a great chap: I'll never forget him.-I rather wish, though, . . . you hadn't told me that he wrote all that rubbish" (Spark, 108-109). Whereas Wharton thought that James would have been "great" without ever writing a line; in this case, the poet diminishes the man.

Wharton's comment on American philistines is perhaps a comment on the failure of Whitman's vision of brotherhood itself. The novella shows how another can shape the course of our lives; it also shows how writing isolates the author from the very people who should compose his or her audience. For Wharton, solitude was a necessary condition for genius, but she yearned, as her love of Whitman illustrates, for a breaking down of the barriers, which separate self from others. "We live in our own souls," Wharton writes in The Touchstone, "as in an unmapped region, a few acres of which we have cleared for our habitation; while of the nature of those nearest us we know but the boundaries that march with ours." 12 In Whitman, she found a fellow marcher, "afoot" 
with visions (Leaves, 55).

California State University, Fresno

\section{NOTES}

Quotes from Edith Wharton are courtesy of the Collection of American Literature, the Beinecke Rare Book and Manuscript Library, Yale University.

1 Edith Wharton, A Backward Glance (New York: D. Appleton-Century, 1947), 185 (hereafter cited as $A B G$ ).

2 Gaillard Lapsley, "E. W.," 34, the Beinecke Rare Book and Manuscript Library, Yale University (hereafter cited as "E. W.").

3 See Richard Moore Bucke, Cosmic Consciousness: A Study in the Evolution of the Human Mind (New York: E. P. Dutton \& Co., 1941), 215-236.

4 Many of Wharton's friends would not have been surprised if she had embraced Catholicism. Lapsley states that "she understood how effectively the formal and impersonal character of the corporate act provided both shelter and free range for the emotions released by ceremony" ("E. W.," 35). See also Percy Lubbock, Portrait of Edith Wharton (New York and London: Appleton-Century-Crofts, 1947), 231-239. Nicky Mariano believed that if Wharton's maid and housekeeper, two devout Catholics, had lived longer, they might have influenced her to convert.

5 Walt Whitman, Leaves of Grass, ed. Jerome Loving (New York: Oxford University Press, 1990), 351 (hereafter cited as Leaves).

6 Edith Wharton, The Custom of the Country (New York: Charles Scribner's Sons, 1913; reprint n.d.), 430 (hereafter cited as $C C$ ).

7 Edith Wharton, "Sketch of an Essay on Walt Whitman," the Beinecke Rare Book and Manuscript Library, Yale University. The pages are unnumbered, but I have parenthetically indicated citations as "Sketch." For other information on the sketch, see Candace Waid, Edith Wharton's Letters from the Underworld (Chapel Hill: The University of North Carolina Press, 1991), 130, 132-133. Waid misreads "intrinsic" for "intimate" in Wharton's description of Whitman's epithets and images.

8 Edith Wharton, "The Criticism of Fiction," The Times Literary Supplement, May 14, 1914, 230.

9 See Alan Gribben, ed., "Edith Wharton's Letters," The Library Chronicle of the University of Texas 31 (1985), 46. Gribben explains that this letter is especially difficult to date but notes that it accords with those Wharton wrote in the latter half of 1910 . It is also published in The Letters of Edith Wharton, ed. R. W. B. Lewis and Nancy Lewis (New York: Charles Scribner's Sons, 1988), 207.

10 R. W. B. Lewis, Edith Wharton (New York: Fromm International Publishing, 1985), 259-260.

11 Edith Wharton, The Spark (New York: D. Appleton, 1924), 81.

12 Edith Wharton, “The Touchstone," Ethan Frome and Other Short Fiction by Edith Wharton (New York: Bantam, 1987), 127. 